\title{
Effect of planting geometry and training on growth and seed yield of tomato (Solanum lycopersicum L.)
}

\author{
Gulshan Ansari', Manohar Lal ${ }^{1}$, H. S. Kanwar ${ }^{2}$, Rajesh Kanwar ${ }^{1}$ and Rohit Verma ${ }^{1}$ \\ ${ }^{1}$ Department of Seed Science and Technology, Dr. Y.S. Parmar University of Horticulture and Forestry, Nauni, \\ Solan-173 230 (H.P.), INDIA \\ ${ }^{2}$ Department of Vegetable Science, Dr. Y.S. Parmar University of Horticulture and Forestry, Nauni, Solan-173 230 \\ (H.P.), INDIA \\ *Corresponding author. E-mail: manoharlal647@gmail.com
}

Received: July 24, 2016; Revised received: February 28, 2017; Accepted: May 17, 2017

\begin{abstract}
The study was conducted to evaluate the effect of planting geometry and training on growth and seed yield of tomato (Solanum lycopersicum L.) using cultivar Solan Lalima during Kharif 2013 at Experimental Farm of Department of Seed Science and Technology, Dr. Y.S. Parmar University of Horticulture and Forestry, Nauni, Solan (H.P.). The treatments comprised of four training levels i.e. $Y_{1}$ (single stem), $Y_{2}$ (double stem), $Y_{3}$ (unpruned with horizontal string) and $Y_{4}$ (unpruned bush stakes (control)) and eight plant densities viz. $S_{1}(60 \times 15 \mathrm{~cm}), S_{2}(60+30 \times 15$ $\mathrm{cm}), S_{3}(60 \times 30 \mathrm{~cm}), S_{4}(60+30 \times 30 \mathrm{~cm}), S_{5}(90 \times 15 \mathrm{~cm}), S_{6}(90+30 \times 15 \mathrm{~cm}), S_{7}(90 \times 30 \mathrm{~cm})$ and $S_{8}(90+30 \times 30 \mathrm{~cm})$. Analysis of variance showed that the treatment combination $Y_{1} S_{7}$ (single stem and plant spaced at $90 \times 30 \mathrm{~cm}$ ) resulted in maximum ripe fruit length and width $(5.86 \mathrm{~cm}$ and $5.06 \mathrm{~cm}$, respectively), maximum number of seeds/fruit (110.67), minimum days to ripe fruit harvest (71.00) and maximum harvest duration (59.84 days) but gave the low seed yield. The combination $\mathrm{Y}_{2} \mathrm{~S}_{5}$ (double stem and $90 \times 15 \mathrm{~cm}$ ) resulted highest seed yield i.e. $519.71 \mathrm{~kg}$ per hectare. Therefore, planting density $S_{5}(90 \times 15 \mathrm{~cm})$ in combination with training system $\mathrm{Y}_{2}$ (double stem) may be recommended for commercial seed production of tomato.
\end{abstract}

Keywords: Cultivar, Plant density, Seed Yield, Training levels

\section{INTRODUCTION}

Tomato (Solanum lycopersicum L.) is an important warm season solanaceous vegetable crop that cannot tolerate frost and freezing temperatures. Tomato is a good source of vitamins, minerals and antioxidants so it is an important ingredient of traditional and modern days' food. The tomato pulp and juice are mild aperients (laxative), a promoter of gastric secretion and act as blood purifier and intestinal antiseptic (Hazra et al., 2011).

Seed is the primary factor which determines the performance of the plants in the field and final yield. So there is need to focus on factors which help in increasing the yields of quality seed. Among various agrotechniques, planting density and training system play a crucial role in quality seed production in tomato as both of these factors helps in preventing overcrowding and reduces the competition between and within the plants for nutrients, light and water thus helps in avoiding poor fruit set and delayed maturity. Also, these factors by improving air circulation through the plants especially in humid areas prevent the proliferation of disease. Maximum yield is resulted at optimum plant density which depends upon cropping system and cultivar (Dong et al., 2006). It is believed that yield per unit area tends to increase with plant density up to certain threshold value, and then tends to decline due to competition between the plants (Duthie et al.,1999). Plant density determines the optimal above ground conditions that allows the plant to get the essential growth elements such as light, $\mathrm{CO}_{2}$, etc. that influence the productivity (Ibrahim, 2012).

Similarly, training and pruning in later stages of plant growth reduces the competition amongst fruits for sunlight and photosynthesis products. For making training more effective, staking is another most important operation being practiced especially during rainy season for improving quality, yield and protecting the crop from attack of soil borne pathogens. Moreover, the traditional system of staking makes plants more bushy posing problems in accommodating more number of plants per unit area. Patil et al. (1973) pointed out that indeterminate plants have unnecessary leaf load and can be severely pruned without effecting yield. By proper pruning and staking, more number of plants can be accommodated per unit area thereby increasing the yields. Keeping in view the above perspectives, the present studies were thus planned to find out optimum training system and plant spacing for commercial seed production of tomato. 


\section{MATERIALS AND METHODS}

The experiment was laid out on $14^{\text {th }}$ March 2013 in split plot design with thirty two treatments $(4 \times 8)$ replicated three times at Department of Seed Science and Technology, Dr. Y.S. Parmar University of Horticulture and Forestry, Nauni, Solan (H.P.) situated between $30.51^{\circ} \mathrm{N}$ latitude and $77.09^{\circ} \mathrm{E}$ longitude in the mid- hill zone of Himachal Pradesh (India).The seedlings of tomato var. Solan Lalima were transplanted at eight different spacings $\left(\mathrm{S}_{1}-60 \times 15 \mathrm{~cm}, \mathrm{~S}_{2}-\right.$ $60+30 \times 15 \mathrm{~cm}, \mathrm{~S}_{3}-60 \times 30 \mathrm{~cm}, \mathrm{~S}_{4}-60+30 \times 30 \mathrm{~cm}, \mathrm{~S}_{5}-$ $90 \times 15 \mathrm{~cm}, \mathrm{~S}_{6}-90+30 \times 15 \mathrm{~cm}, \mathrm{~S}_{7}-90 \times 30 \mathrm{~cm}, \mathrm{~S}_{8}-$ $90+30 \times 30 \mathrm{~cm}$ ) in a plot having size of $3.6 \mathrm{~m} \times 1.8 \mathrm{~m}$. After the plants established, they were trained to four levels i.e. $\mathrm{Y}_{1}$ (single stem), $\mathrm{Y}_{2}$ (double stem), $\mathrm{Y}_{3}$ (unpruned with horizontal string) and $\mathrm{Y}_{4}$ (unpruned bush stakes (control). FYM and fertilizers were applied as per package of practices for vegetable crops, Directorate of Extension Education, Dr. Y.S. Parmar University of Horticulture and Forestry, Nauni, Solan (H.P.).

The observations were made on five randomly selected plants from each replication. The growth characters studied were plant height $(\mathrm{cm})$ before the senescence, days to ripe fruit harvest and harvest duration. Fruits from the selected plants were collected to record fruit characters such asripe fruit weight $(\mathrm{g})$, ripe fruit length $(\mathrm{cm})$, ripe fruit width $(\mathrm{cm})$ and number of ripe fruits per plant. Seeds from the harvested fruits were extracted and dried to safer moisture limit i.e. $6-8 \%$ and seed yield attributes like number of seeds per fruit, seed yield per plant $(\mathrm{g})$ and seed yield per hectare $(\mathrm{kg})$ were calculated.Statistical analysis of the recorded data was carried out as per design of the experiment as suggested by Gomez and Gomez (1984).

\section{RESULTS AND DISCUSSION}

Effect on growth characters: All the growth characters were influenced by the given treatments as revealed in Table 1. Plant height is an important character as it leads to the production of quality fruits and ultimately high yield of quality seeds. However, plant height being a genetically controlled character also influenced by the environment to a great extent. In the present studies, the plant height decreased with decrease in spacing. The tallest plants $(159.02 \mathrm{~cm})$ were recorded with widest plant spacing of $90 \times 30 \mathrm{~cm}$ $\left(\mathrm{S}_{7}\right)$, whereas, among the training systems single stem trained plant resulted in tallest plants $(150.19 \mathrm{~cm})$. Aminifard et al. (2012) reported maximum plant height and lateral stem length at wider plant spacing $(30 \times 100 \mathrm{~cm})$ in capsicum. Lal et al. (2014) also reported tallest plants with wider spacing and single stem pruned plants in capsicum. This may be due to the pinching shoots at their emergence and ultimately diverting the flow of nutrients and manufactured food

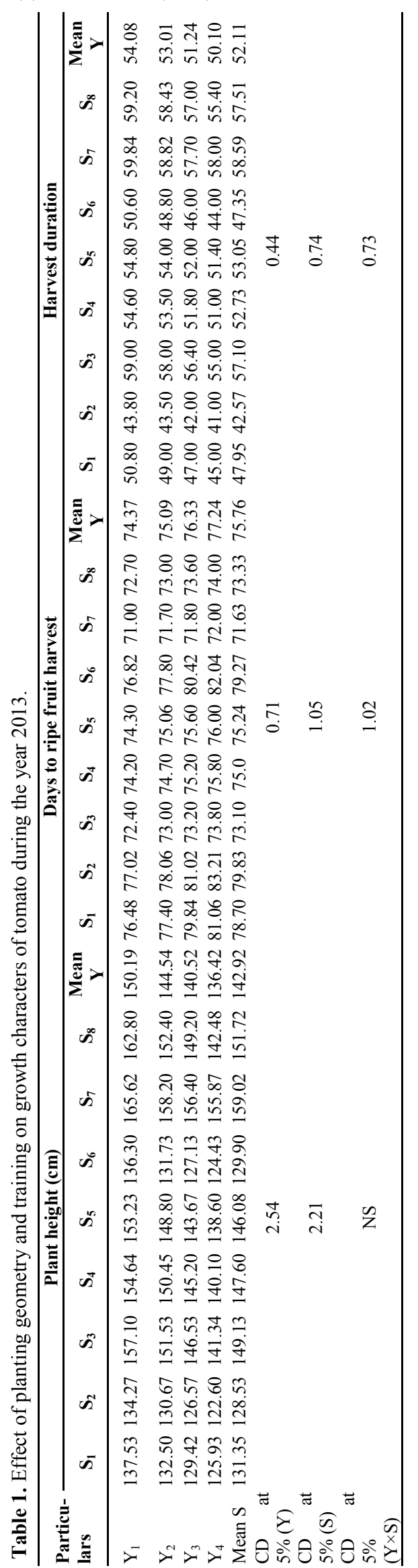


Gulshan Ansari et al. / J. Appl. \& Nat. Sci. 9 (2): 1146 - 1150 (2017)
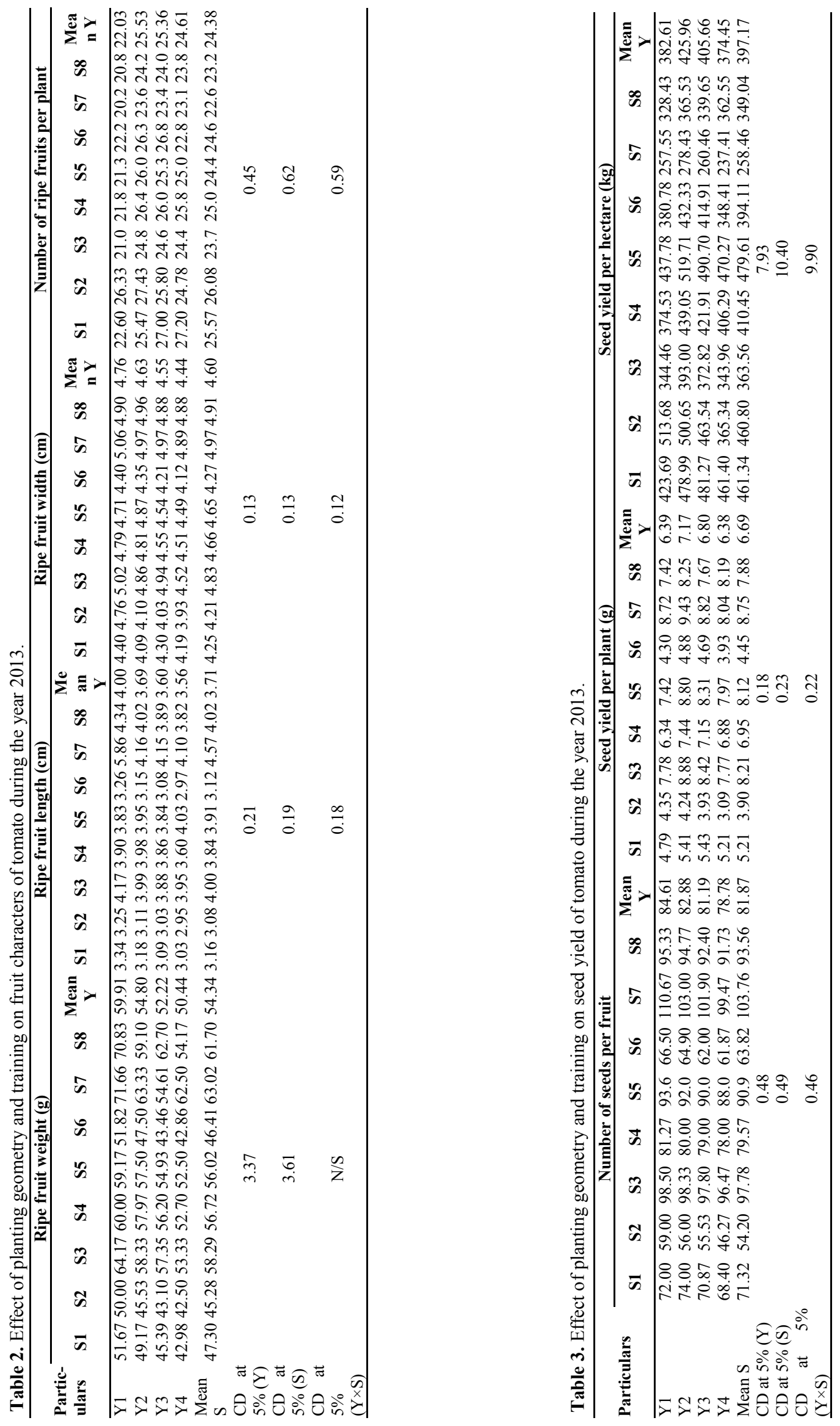
material towards apical growing point and greater exposure of plants to light leading to higher photosynthetic activities.

Minimum number of days to ripe fruit harvest (71.00) and maximum harvest duration i.e. 59.84 days were reported with the interaction $\mathrm{Y}_{1} \mathrm{~S}_{7}$ (single stem and $90 \times 30 \mathrm{~cm}$ ) which may be because of availability of sufficient nutrients and light to the plant due to wider spacing that results in accumulation of maximum photosynthates and induction of early flowering compared to closer spacing and thus enhancing better growth and development of the fruit. The results are in conformity with Tanaka and Komachi (1982) who reported that high plant density delays fruit ripening by seven days. Lal et al. (2014) also reported minimum number of days to ripe fruit harvest with wider spacing and low shoot density in bell pepper. Similar findings were also observed by Bhatnagar and Pandita (1979) who have reported that least number of days was taken for ripening in closely spaced tomato plants. Similar results were obtained by Verma (2014) who reported that double row $(75+45) \times 45 \mathrm{~cm}$ and triangle method of planting was superior in terms of growth characters such as plant height and days to ripe fruit harvest.

Effect on fruit characters: The treatments significantly affect different fruit characters as depicted in Table 2. Ripe fruit weight is an important character which contributes to the fruit/seed yield and seed quality. Spacing $90 \times 30 \mathrm{~cm}\left(\mathrm{~S}_{7}\right)$ gave the highest average ripe fruit weight $(63.02 \mathrm{~g})$ whereas in case of training single stem trained plants resulted in highest ripe fruit weight i.e. $59.91 \mathrm{~g}$. The increased fruit weight at widest spacing may possibly be due to more availability of light, reduced competition for nutrients and moisture, hence, more assimilation of carbohydrates. Similar results has been recorded by Sharma (2001) who have reported that widely spaced paprika plants produces more number of fruits per plant and heavier fruit weight and Elattir (2002) reported that increased plant density in tomato results in increased number of clusters per $\mathrm{m}^{2}$ and fruit yield but mean fruit weight decreases. Similarly, Buitelaar and Eelhart (1986) reported that each ten centimeters of closer spacing tended to decrease average tomato fruit weight by about 5 grams but increase yield by $1.6 \mathrm{~kg} / \mathrm{m}^{2}$. Results are also in conformity with Lal et al. (2014), who have an increase in average fruit weight when plants were pruned to single stem in Capsicum annuum.

Fruit length and width determine the size of the fruit and correlated to the number of seeds per fruit (Kinet and Peet, 1997). Maximum fruit length and width $(5.86 \mathrm{~cm}$ and $5.06 \mathrm{~cm}$, respectively) were obtained with interaction level $\mathrm{Y}_{1} \mathrm{~S}_{7}$ (single stem and $90 \times 30$ $\mathrm{cm})$. The possible explanation remains the same as the plants at wider spacing has less competition between and within the plants for nutrients, sunlight and aerial space resulting in better growth and development of the plant. Papadopoulas and Pararajasingham (1997) also concluded that narrow spacing was found to have a detrimental effect on the fruit size in tomato. Similarly, Neamati and Kruchkov (2002) reported that plants with more fruits are positively correlated to less growth and smaller fruits. The results are also in agreement with Lal et al. (2014), who reported maximum fruit length and width with single stem trained plant and wider spacing in capsicum. Sumiati (1987) concluded that highest yield was obtained from plants pruned to two or three stems; however pruning to single stem produces larger size fruits.

Number of ripe fruits per plant is a major seed yield contributing character. Interaction $\mathrm{Y}_{2} \mathrm{~S}_{2}$ (double stem and $60+30 \times 15 \mathrm{~cm}$ ) resulted in maximum number (27.43) of ripe fruits. Similar findings were observed by Hassan (1991) who concluded that highest number of fruits per plant was recorded in plants pruned to double stem. This could be due to the double stem character along with close spacing accommodate more number of plants that results in more number of fruits per unit area.

Effect on seed yield characters: The treatments have significant effect on the seed yield attributes as shown in the Table 3 . The main and important objective of any seed production experiment is to have optimum seed yield per unit area and to have better returns. Number of seeds per fruit is one of the characters contributing to final seed yield. Maximum numbers of seeds per fruit (110.67) were recorded with treatment combination $\mathrm{Y}_{1} \mathrm{~S}_{7}$ (single stem and $90 \times 30 \mathrm{~cm}$ ). Lal et al. (2016) reported similar results in bell pepper. This might be due to the reasons that wider spaced and single shoot trained plants bear larger sized fruits while closer spaced and dense shoots per plant resulting in small sized fruits and size of fruit is correlated to number of seeds (Kinet and Peet, 1997).

Treatment combination $\mathrm{Y}_{2} \mathrm{~S}_{7}$ (double stem and $90 \times 30$ $\mathrm{cm})$ recorded maximum $(9.43 \mathrm{~g})$ seed yield per plant while interaction $\mathrm{Y}_{2} \mathrm{~S}_{5}$ (double stem and $90 \times 15 \mathrm{~cm}$ ) gave the highest seed yield per hectare $(519.71 \mathrm{~kg})$ which was at par with $\mathrm{Y}_{1} \mathrm{~S}_{2}$ (single stem and $60+30 \times 15$ $\mathrm{cm})$. Sanchez et al. (1993) reported lower seed yield with closer spacing in bell pepper. However Singh et al. (1989) and Khurana et al. (2002) reported lower seed yield with wider spacing in chilli. Double stem trained plants resulted in larger sized fruits with bold seeds having more test weight. Genard et al. (2009) who reported that there is a positive correlation between fruit weight, 1000 seed weight and germination. Lal et al. (2016) reported plants trained to two stems and spaced at $45 \times 30 \mathrm{~cm}$ resulted in higher seed yield. Also the appropriate spacing accommodated more number of plants which increase per unit yield as well as profit of the producers. 


\section{Conclusion}

From the present investigations it can be concluded that treatment combination $\mathrm{Y}_{1} \mathrm{~S}_{7}$ (single stem and plant spaced at $90 \times 30 \mathrm{~cm}$ ) resulted in maximum ripe fruit length and width $(5.86 \mathrm{~cm}$ and $5.06 \mathrm{~cm}$, respectively), maximum number of seeds/fruit (110.67), minimum days to ripe fruit harvest (71.00) and maximum harvest duration (59.84 days) but gave the low seed yield. Whereas $\mathrm{Y}_{2} \mathrm{~S}_{5}$ (double stem and $90 \times 15 \mathrm{~cm}$ ) was found superior over all other treatments except $\mathrm{Y}_{1} \mathrm{~S}_{2}$ (single stem and $60+30 \times 15 \mathrm{~cm}$ ) which was found statistically at par in terms of economic character i.e. seed yield per hectare $(519.71 \mathrm{~kg})$ which is an ultimate goal of any experiment. Therefore, planting density $\mathrm{S}_{5}(90 \times 15 \mathrm{~cm})$ in combination with training system $\mathrm{Y}_{2}$ (double stem) can be recommended for commercial cultivation after multi-location testing for getting the higher yield of quality seeds in tomato under open field conditions in Himachal Pradesh.

\section{REFERENCES}

Aminifard, M.H., Aroiee, H., Ameri, A. and Fatemi, H. (2012). Effect of plant density and nitrogen fertilizer on growth, yield and fruit quality of sweet (Capsicum annuum L.) in response to plant density. Afr. J. Agri. Res.7 (6): 859-866.

Bhatnagar, D.K. and Pandita, M.L. (1979). A note on the effect of nitrogen, phosphorous and spacing on growth and yield of tomato cultivar HS-102. Har. J. Hort. Sci. 8 (1-2):73-75.

Buitelaar, K. and Eelhart, I. (1986). Closer planting with tomatoes: Fashionable Fantasy or rock hard data. Groen. on Fruits 42(15):28-31.

Dong, H., Li, W., Tang, W., Li, Z., Zhang, D. and Niu, Y. (2006). Yield, quality and leaf senescence of cotton grown at varying planting dates and plant densities in the Yellow River Valley of China. Field Crops Res. 98: 106-115.

Duthie, J.A., Shrefler, J.W., Roberts, B.W. and Edelson, J.V. (1999). Plant density dependent Variation in marketable yield, fruit biomass and marketable fraction in watermelon. Crop Sci.39:406-412.

Elattir, H. (2002). Plant density effects on processing tomato grown in Morocco. Acta Hort. 613: 197-200.

Genard, M., Gibert, C., Bruchou, C. and Lescourret, F. (2009). An intelligent virtual fruit model focusing on quality attributes. J. Hort. Sci. and Biotech. 51:157163.

Gomez, K.A. and Gomez, A.A. (1984). Statistical Procedure for Agricultural Research. New York: John Wily, New York.

Hassan, J.K. (1991). Tomato hybrid seed production in unheated plastic tunnels. Zoldsegt. Kut. Int. Bull.,24:9396.

Hazra, P., Chattopadhyay, A., Karniakar, K. and Dutta, S. (2011). Modern Technology in Vegetable Production. New Delhi: Publishers, New Delhi.

Ibrahim, H.M. (2012). Response of some sunflower hybrids to different levels of plant density. APCBEE Proced. 4: 175-182.

Khurana, D.S., Parmar, P., Hundal, J.S. and Kanwar, J.S. (2002). Effect of plant population density and parental row ratio on hybrid seed production in chilli (Capsicum annuum L.). J. Res., PAU. 39(4): 499-503.

Kinet, J.M. and Peet, M.M. (1997). The Physiology of Vegetable Crops. CAB International, UK.

Lal, M., Kanwar, H.S. and Kanwar, R. (2014). Impact of spacing and training on seed yield of capsicum, Capsicum annuиm L. under protected conditions. International Journal of Farm Sciences 4(3): 42-48.

Lal, M., Kanwar, H.S., Kanwar, R. and Lal Chaman (2016). Effect of planting density and training on plant health and seed quality of bell pepper (Capsicum annuum L.) under protected conditions. Journal of Applied and Natural Science 8 (3): 1219 - 1222.

Neamati, S.H. and Kruchkov, A.V. (2002). Estimating the combining ability on average mass and number of fruits on a plant 8 sterile and 10 fertilized tomatoes lines. Izvestia. Moscow Agri. pp. 81-89.

Papadopoulas, A.P. and Pararajasingham, S. (1997). The influence of plant spacing on light interception and use in greenhouse tomato (Lycopersicon esculentum Mill.). A review of Scient. Hort. 69(1-2): 1-29.

Patil, V.K., Gupta, P.K. and Tombre, P.G. (1973). Influence of pruning, mulching and nitrogenous fertilizer on the growth, yield and quality of staked plants of 'Sioux' variety of tomato. Veg. grower 8: 4-9.

Sanchez, V.M., Sundstroml, F.J. and Lang, N.S. (1993). Plant size influences bell pepper seed quality and yield. Hort. Sci., 28(8): 809-811.

Sharma, S.K. (2001). Effect of nitrogen and spacing on seed production of paprika. Veg. Sci. 28(2): 175-176.

Singh, S.B., Singh, T., Singh, B.N. and Singh, S.S. (1989). Growth and yield of chilli (Capsicum annuum L.) in relation to zinc levels and number of seedlings/hill. Hort. Sci. 18(1-2): 113-118.

Sumiati, E. (1987). Effect of pruning on yield and quality of tomato cultivars Gondol and Intan. Bul. Penel. Hort. 15 (1): 48-54.

Tanaka, M. and Komachi, S. (1982). Effect of plant density and topping on growth and yield of green house tomatoes. Res. Bull. Hort. Nat. Agri. Exp. Station 185:83-99.

Verma, R. (2014). Effect of mulching and planting geometry on seed production in bell pepper (Capsicum annuum L.). M.Sc. Thesis, Department of Seed Science and Technology, Dr. YS Parmar University of Horticulture and Forestry Nauni, Solan (Himachal Pradesh)-India. 